\title{
The Use of Ateji as Figurative Speech in Japanese Song Lyrics
}

\author{
Faustina Ardisa, Utari Novella \\ Faculty of Humanities \\ Bina Nusantara University, Jakarta, Indonesia \\ ardisafaustina@yahoo.com,utari.novella@binus.edu
}

\begin{abstract}
A B S T R A C T
This study aims to analyze the types of ateji used in Japanese song lyrics, and to analyze ateji as a form of figurative speech by the semantic-semiotic connection between the words used in ateji's writing and reading. Analysis is done qualitatively based on Shirose's theory of ateji classification and Japan's hiyu hyougen (figurative speech) theory. This research resulted in the finding of 4 ateji types in Japanese song lyrics, which are ateji for foreign words pronunciation, ateji for pronouns, ateji for replacing words, and ateji for words used in specific titles/works. The use of metaphor (in'yu), metonymy (kan'yu), and synecdoche (teiyu) are also found between the uses of ateji, based on the relation of the words in said ateji. The words can be linked through contextual relation, conceptual relation, or semantical relation. The connection of the words can also result in similar uses as other figurative speeches not included in Japanese's hiyu hyougen, which indicated that ateji can be handled and understood as a general form of figurative speech in written Japanese language.

$$
\text { K E Y W O R D S }
$$
\end{abstract}

Ateji; Figurative Speech; Semantics; Semiotics; Song Lyrics

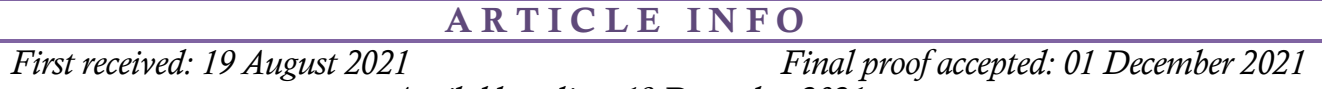

Available online: 19 December 2021

\section{INTRODUCTION}

Japanese songs are getting more reputation through the internet. The uses of OSTs (original soundtracks) in Japanese anime, games, or dramas also provides more exposure on the spread of the songs. As Japanese cultures gain more recognition internationally, more people also gain interests in learning the language itself. Some Japanese language learning videos are even created on platforms such as YouTube using Japanese songs as its media of learning. The use of songs for learning can be seen as practical, as the song lyrics does not need to be dubbed when it plays outside of Japan, as opposed to other Japanese pop cultures that need to be translated before it can be sold to foreigners (e.g., comic/manga, movies, etc.). But the learning of Japanese is not easy. To understand the text, one would have to learn to read at least three types of characters, which are Hiragana, Katakana, and Kanji. To add it up, some kanji are not always read as how the reading rules (known as on'yomi and kun'yomi) stated. These combination of irregular kanji readings are known as ateji.

Ateji is a form of written expression, usually containing kanji with an irregular way of reading written as furigana, which is a small font on top of the Kanji (Lewis, 2010). Ateji can also be written with numbers or alphabets as long as it has an 
irregular way of reading, sometimes even read as a whole different word with different meaning from the characters (Shirose, 2012). Ateji are mostly found on written documents, such as magazines, novels, or comic books, but this written expression is also used on song lyrics despite the nature of songs that are mostly heard but not seen.

Shirose (2012) classified ateji into 7 different types, which are ateji of mouth speak, ateji of foreign language, ateji of foreign abbreviation, ateji of sport terms, ateji of pronouns, ateji of word substitution, and ateji of specific works. For example, ateji of pronouns are written like 喫煙所 (あそこ) with the kanji of 'kitsuensho' (smoking area) pronounced as 'asoko' (there). In that example, the furigana 'asoko' indicates the speaker way of talking, while the kanji showing explicitly what place the speaker was pointing at.

The practice of using different words to tell different meanings not only happened in ateji but is also shown in many other languages, universally known as figure of speech. In Indonesian, figure of speech is known as 'majas', while in Japanese it is called as 'shuujihou' or 'hiyu hyougen'. In essence, majas and shuujihou are both technique of wording things, to get one's point understood by audiences and having a certain effect on them (Nillas \& Nufus, 2014; Prihantini, 2015; Yuasa, Itoku, Iwai, Oketani, Nagamatsu, Minami, \& Yamami, 2011). Japanese hiyu hyougen is a type of shuujihou that specializes in seeing things as another thing and comparing them (Nakazawa, 2020). Included in hiyu hyougen are similes, metaphors, metonymy, synecdoche, and personification (Moriyama (2010) and Moriyama \& Fukasa (2003) in Lee, 2020; Nakazawa, 2020).

Even in the Japanese language itself, figurative speech is already used on a daily basis. For example, Ana and Divna (2012) stated the kanji for "hand" (手) is used to create compound words in Japanese and Chinese dictionaries, with the kanji used metonymically to symbolize a person who is skilled with their hands/techniques. The metonymic use of "hand" kanji resulted in professional words such as "singer" to be written as 歌手 (kashu) using the kanji for "song" and "hand". Other than metonymic uses, Lee (2020) also found how a word in Japanese language can have many functions - reaching up to 11 uses from the perspective of metaphor, synecdoche, and metonymy. Yet, none of the research connected figurative speech with ateji.

With the amount of figurative speech used in Japanese language, it is deemed possible to for ateji to be used as another way of showing figure of speech in literatures. After all, ateji and figure of speech have the same characteristics, as both are utilizing different words for showing different meanings. For example, there is one ateji used in a song titled "More Than You, Less Than Me" (キ ミ以上、ボク未満。) where the songwriter uses the kanji 'shinchuu' (heart/mind) to write what is sung as 'sekai' (world). The more detailed explanation of the lyric can be seen below.

世界は君以上で溢れかえってる (Deco*27, 2009)

Sekail wa/ kimil ijou/ del afurekaetteru

World/ particle/ you/ more/ particle/ overflowing

The world is overflowing with people better than you

でも僕の心中(せかい)には君しかいないから

Demo/boku/ no/ shinchuu/ ni wa/ kimi/ shika/ inail kara

But/ I/ particle/ heart/ particle/ you/ except/ no one/ because

But there is no one except you in my world

The words in the corresponding ateji are not related semantically, whereas one means the heart/mind of the singer, while the other one means the world. Yet, those words are connected through the content of the song - a love song sung for one's lover. The ateji used in the song above is comparing the singer's heart with the world, and replacing the way of reading the kanji likewise. This ateji use shares similar concept with metaphor, where two different things can be seen as the same, and the missing words of comparison (e.g., as brave as a lion, crazy like a fox, etc.) between utilized words. This ateji shows the difference between the word 'sekai' (world) stated at the first line of the lyric and at the second line of the lyric, and it shows that ateji is indeed a form of figure of speech just like other majas or shuujihou.

The result of this research is expected to prove to use of ateji found in Japanese song lyrics as figure of speech whether in Japanese sense or other languages. To make the classification easier, the figure of speech found in ateji will be correlated with Shirose's theory of ateji types. With the understanding of ateji as a figure of speech, Japanese learners will be able to 
understand the use of ateji in a more relatable way, as figure of speech are used more internationally compared to the Japan-exclusive ateji.

\section{METHODS}

This research used qualitative-descriptive approach, in which the researcher will be the key instrument to analyse the collected data (Sugiyono, 2013). This approach is chosen as the data used in this research is formatted as words and not numbers, unless there are numbers that are directly related to the analysed phenomenon.

The data are in the form of atejis found in Japanese songs, collected with literature study method. The atejis are known by looking through song lyrics of various sources, including official lyric videos or music videos, lyrics citing sites, or the songwriters' personal blogs. Songs that do not have ateji in them are not listed as data. In result, there are 50 sets of ateji collected from 30 Japanese songs, with all of them released on year 2009-2020 period.

To understand different words used in one ateji, the data will be written as lines from the song lyrics. The gloss is written in the order of 1) Original Japanese lyrics, 2) Romanized reading based on the kanji or the way the lyrics is written as, 3) Meanings of each Romanized words, 4) Translation of the full line including the meaning of how the ateji is read as. The ateji used for data analysis will be underlined.

The analysis for will be done semantically and semiotically to determine on how do the words within the ateji data are connected with each other, and what do they represent regarding the context of the song. The context will be seen from the full song lyrics and the plot of its respective official music video. The uses of ateji in Japanese song lyrics will be compared to previously mentioned Shirose's theory of ateji classification and theory of figurative speech from various sources. Results of ateji types and figurative uses found in Japanese song lyrics will also be compared to see better correlation of the ateji uses. The result of the analysis will be presented in sentences and tables.

\section{RESULT AND DISCUSSION}

Since ateji are mostly used in written works such as novels and magazines, most ateji research are done with Japanese manga or comic books as its resources. Nevertheless, the uses of ateji are not limited to written works but are also represented in songs, though it is rarely recognized. Not only that, the use of ateji have never been recognized as figurative speech. As so, it is necessary for ateji found in song lyrics to be analysed on the ateji types found in it and figurative speech found within the ateji. Analysis of stated topics are written below.

\section{Ateji Types Found in Japanese Song Lyrics}

Depending on its functions, ateji can be classified into ateji of mouth speak, ateji of foreign language, ateji of foreign abbreviation, ateji of sport terms, ateji of pronouns, ateji of word substitution, and ateji of specific works (Shirose, 2012). The ateji types found in the data and its frequencies are summarized in the Table 1.

Table 1: Analysis Result of Ateji Types.

\begin{tabular}{|l|c|c|}
\hline \multicolumn{1}{|c|}{ Ateji Type } & Frequency & \% \\
\hline Ateji of foreign language & 6 & 12 \\
\hline Ateji of pronouns & 3 & 6 \\
\hline Ateji of word substitution & 38 & 76 \\
\hline Ateji of specific works & 3 & 6 \\
\hline
\end{tabular}

As seen from Table 1, the highest frequency of ateji found from the data was 'ateji of word substitution' (38 times), followed by 'ateji of foreign language' (6 times), while 'ateji of pronouns' and 'ateji of specific works' used with the lowest frequencies (3 times). The analysis of each ateji based on their type is presented below.

Data 1:

フェアリィテイル
まるで 御伽噺 (orange, 2018)
Marude/ otogibanashi
Just like/ fairy-tale
Just like a fairy-tale

The Data 1 above uses two different languages on its ateji. The kanji is usually read as "otogibanashi", but in this case, it is read as "fairytale". In Japanese dictionary and English 
dictionary, both words used in the sentence have the same meaning, whereas both are stating a fantastical story meant for kids. Thus, it can be concluded that Data 1 is translating the words from Japanese kanji to English words acting as its furigana, or the other way around. This translating function is the characteristics of ateji of foreign language, as stated by Shirose (2012).

Data 2:

$$
\text { きみ }
$$

祈っても王子様はまだ来ない (Noboru, 2010)

Inottemo/ oujisama/ wa/ mada/ konai

Even praying/ prince/ particle/ not yet/ come

Even though (I) pray, you haven't come yet

In Data 2, the ateji is read as "kimi", despite the kanji sound "oujisama". In Japanese, "oujisama" is a way of calling a prince, meanwhile "kimi" is a pronoun, literally translated as "you". In this ateji, the kanji in the lyrics are stating who does the lyric meant when it sang the pronoun "you". The use of pronoun paired with the subject of it stated in the kanji means that this ateji is classified as ateji of pronouns.

Data 3:

$$
\text { はこ }
$$

この小さな劇場から出らんない (Eve, 2017)

Kono/ chiisana/gekijou/ kara/derannai

This/ small/ theater/ from/ can't go out

Can't go out from this small theater box

In Data 3, two completely different words are used in the ateji's written text and pronunciation. The kanji, read as "gekijou" means "theater", while the furigana is read as "hako" or "box". The Japanese dictionary stated that gekijou is defined as "a building used to show stage play, movies, shows, etc., to audiences". Meanwhile, hako is "a case made of wood etc., usually shaped in cubes, as a container for things".

Ateji that uses completely different meanings in the kanji and furigana such as seen in Data 3 is categorized as ateji of word substitution. This type of ateji does not only substitute words that has completely different meanings, but also conclude ateji that uses words that has similar meaning yet completely different pronunciation as its furigana. The example of such case can be seen in Data 4.

Data 4:

$$
\text { さだめ }
$$

互いを裁き合う宿命だから (40meterP, 2013)

Tagai/ wo/ sabakiau/ shukumei/ dakara
Each other/ particle/ to judge each other/ fate/ because

Because we are fated to judge each other

Data 4 uses "shukumei" as its kanji while it is pronounced as "sadame". Even so, both words can be translated as "fate" or "destiny" and is synonymous. The difference between sadame and shukumei is, sadame can also be translated as "decision" or "agreement". Though it uses similar word meanings in it, this ateji still counts as ateji of word substitution. Due to the different pronunciation of the kanji and furigana. The main function of this ateji type is bestowing a different layer of meaning to each term used inside the ateji by using slightly or completely different words as its kanji and furigana.

Data 5:

$$
\text { はま }
$$

深水に腫魔る恋模様（Deco*27, 2019)

Fukami/ ni/ shu/ maru/ koimoyou

Deep waters/ particle/ tumor/ demon/ relationship

Our relationship is plunging into deep water

Ateji used in Data 5 above is unique, as it uses non-existent words as its kanji. Though the furigana "hamaru" can be understood as "falling" or "sinking", the kanji compound word "shumaru" cannot be found in the Japanese dictionary. It can be concluded that in this ateji, the songwriter created a word to fit the context of the song. A word created by one person or group that is not widely used cannot be defined semantically as it does not officially exist. This results a creation of ateji words that can be used exclusively by one author or in a single title of works. And thus, this type of ateji is called ateji of specific works by Shirose (2012).

\section{Ateji as Figurative Speech}

Ateji as figurative speech analysis will be centered on categories found in Japanese hiyu hyougen. Hiyu hyougen consists of chokuyu/simile, in'yu/metaphor, kan'yu/metonymy, teiyu/synecdoche, and gijinka/personification (Nakazawa, 2020).

Frequencies of each hiyu hyougen and figurative speech found in the usage of ateji are summarized in Table 2. 
Table 2: Figurative Speeches Found in Usage of Ateji.

\begin{tabular}{|l|c|c|c|c|c|}
\hline \multicolumn{1}{|c|}{ Ateji Type } & $\begin{array}{c}\text { Meta- } \\
\text { phor }\end{array}$ & $\begin{array}{c}\text { Meto- } \\
\text { nymy }\end{array}$ & $\begin{array}{c}\text { Synec- } \\
\text { doche }\end{array}$ & Others & None \\
\hline $\begin{array}{l}\text { Ateji of } \\
\text { foreign } \\
\text { language }\end{array}$ & - & - & - & - & 6 \\
\hline $\begin{array}{l}\text { Ateji of } \\
\text { pronouns }\end{array}$ & - & - & - & 1 & 2 \\
\hline $\begin{array}{l}\text { Ateji of word } \\
\text { substitution }\end{array}$ & 6 & 7 & 12 & 13 & - \\
\hline $\begin{array}{l}\text { Ateji of } \\
\text { specific } \\
\text { works }\end{array}$ & 1 & 1 & - & 1 & - \\
\hline $\begin{array}{c}\text { Total } \\
\text { Frequency } \\
\text { (\%) }\end{array}$ & $\mathbf{1 4 \%}$ & $\mathbf{1 6 \%}$ & $\mathbf{2 4 \%}$ & $\mathbf{3 0} \%$ & $\mathbf{1 6 \%}$ \\
\hline \multicolumn{2}{|l}{}
\end{tabular}

As seen from Table 2, the highest frequency of figurative speech found in the use of ateji was synecdoche (24\%), followed by metonymy (16\%), and Metaphor (14\%). However, there is $30 \%$ of ateji that are not included in hiyuu hyougen which classified into 'Other', while there is also $16 \%$ of ateji that do not function as figurative speech and classified into 'None'.

The use of each ateji based on their type of figurative speech is presented further in subsections below.

\section{Ateji as Metaphor}

In metaphor, an object is described by using a completely different object, without the use of comparative words (Nakazawa, 2020; Yuasa et al, 2011). Metaphors are based similarities found between the compared objects ( Lee, 2020).

\section{Data 6:}

決して離さない想いは届いた $\quad(\mathrm{CHiCO}$ with

HoneyWorks, 2015)

Kesshite/ hanasanail omoi/ wa/ todoita

Ever/ to not let go/ feelings/ particle/ reached

(My) never-changing answer has reached (you)

Data 6 is taken from a song titled アイのシナ リオ/Love Scenario. The song centered around "repeating fate" as its narrative, in which three characters keeps repeating same situations even after their rebirth. In the plot of the story, a male character keeps protecting a female character from the villain, and even though he was aware of the repeating plotline, his actions will never change; he will protect the female character.

In the ateji, the lyrics read as kotae/answer, while the kanji "omoi" means feeling/thoughts. In other words, the lyrics in Data 6 is comparing the character's feeling/resolution as an answer. This metaphorical use of the word "answer" to symbolize the character's feeling happened due to the context of the song, whereas the male lead is answering his destiny with his strong feelings of wanting to protect the female lead. To top it off, this comparison does not happen explicitly, just like how metaphors are used.

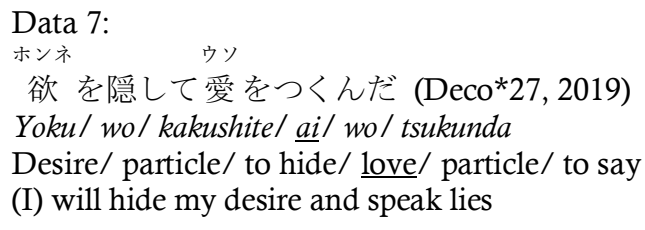

The song, titled as スクランブル交際 /Relationship Scramble, tells the story of a guy who lost his lover and is trying to find new relationships as a form of denying his own pain. The song lyrics stated that the lead character is seeking "instant love" and in the video, it is shown that he has relationship many girls at one time, though none of them seemed to last.

The line in Data 7 comes in as the character is saying "then, I will hide my wishes and lie for someone's sake." Though the lyrics are sung as "lie" the kanji is written as "love". The word "love" and "lie" in this song is related by its theme of shallow relationship, in which the character is saying out lies as a form of love for his partners, cherishing them in a twisted way. Thus, in this song, the word uso/lie is metaphorically taken as ai/love, as what is written on the lyrics.

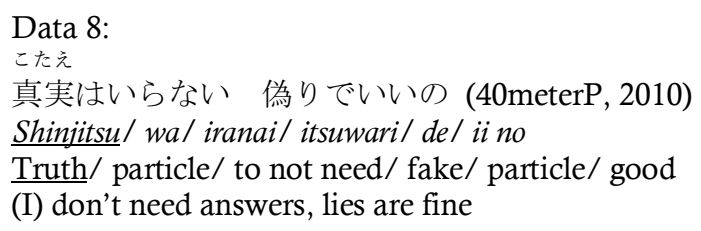

In a song titled トリノコシティ/Torinoko City, the singer is narrated as someone cold, as she keeps pushing people away from herself. In the lyrics the singer asked weird questions to others as an attempt to do so. The quirkiness of the character is shown by asking someone to answer her question within designated word counts. Even though the first part of the song clarified that she is fine with being alone, in the latter part, it is stated that she can't stand being alone, and wanted somebody to stay by her side. 
The lyrics quoted in Data 8 exists in the second half of the song. After throwing out weird questions to other people, in the end, the lyrics said that she "doesn't need answers" and is okay with being lied to. In the line, the word "kotae" or "answer" is written with the kanji "shinjitsu" or truth. In that sense, it can be understood that the word "answer" is used to symbolize the meaning "truth", which is why the lyrics can be followed with "lies are okay".

\section{Ateji as Metonymy}

Metonymy is a way to replace words used in sentences with other words that are tightly related with each other (Nakazawa, 2020; Lee, 2020). For example, Beethoven is highly related with music, and the name can be used as metonymy in the sentence: I'm playing Beethoven. In other words, metonymy uses words that are tightly related to each other, and the correlation are widely known by people, like trademarks (Nillas \& Nufus, 2014; Prihantini, 2015).

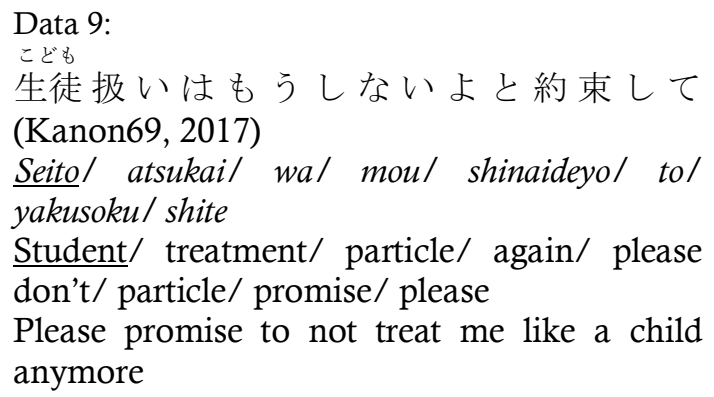

The word seito/student in this data is read as kodomo/child. Semantically, kodomo means a person who is yet of age, meanwhile seito means students in primary and secondary school or elementary school, junior high school, and senior high school. From that semantic aspect, it can be known that seito and kodomo are both speaking about somebody who is not an adult. With that concept in mind, the ateji in Data 9 works as a metonymy, especially when the song's theme is revealed as a song about forbidden relationship between a high school student with her teacher.

Data 10:

望んだ過去から続く (Ito, 2016)

Nozonda/ kako/ kara/ tsuduku

Wished/ past/ from/ to be continued

Continuing from my desired past
じぶん

Genzai/ ni/ nareru/ youni/ kaereba/ ii

Present time/ particle/ can be/so that/ if changed/ good

It would be good if it changed, so I can be myself

Ateji in Data 10 came from a song titled as Time Traveler, a song about the invention of time machine. In the lyrics mentioned above, the singer is thinking about going back to the past. The ateji then appears with genzai/present as its kanji and jibun/oneself as its furigana.

Though it is not completely connected by the context of the song, the words in this ateji shares the same concept of "existing in front of one's eye". The singer is thinking of going to the past to change it, yet he hopes for the present to not change. It can be concluded that the words genzai and jibun are metonymic because in the lyric line, the ateji shows how the singer values his present self, and the kanji works to highlight his statement.

Data 11:

$$
\begin{aligned}
& \text { キミが居るこの地球を 忘れたくはないん } \\
& \text { だよ (Natsushiro, 2017) } \\
& \text { Kimi/ ga/ iru/ kono/ chikyuuu/ wo/ wasure/ } \\
& \text { taku/wa/ naindayo } \\
& \text { You/ particle/ to exist/ this/ Earth/ particle/ } \\
& \text { to forget/ to want/ particle/ not } \\
& \text { I don't want to forget this star where you exist }
\end{aligned}
$$

The use of hoshi/star and chikyuu/Earth as a set of ateji can be found in many songs. One of them exists in the song above, titled ニア (Near). Semantically, the words in ateji above are related to each other, as both star and Earth are astronomical objects. But stars are twinkling, burning celestial bodies, meanwhile Earth is a planet filled with water where life forms exist. With that difference, the ateji as used in Data 11 works as metonymy, since the only common point between stars and Earth - the concept of them as astronomical objects - works to show a place that is neither a star or Earth, as it is shown in Near music video that the story of the song happened in a foreign, unknown planet. 


\section{Ateji as Synecdoche}

Synecdoche is a figure of speech where one part of a thing is used to refer to the whole thing, or the reverse, stating an object to point out one specific part of it (Lee, 2020; Nillas \& Nufus, 2014; Prihantini, 2015; Waridah, 2014). The use of a general word to refer to a more specific terms of the word also counts as synecdoche (Nakazawa, 2020).

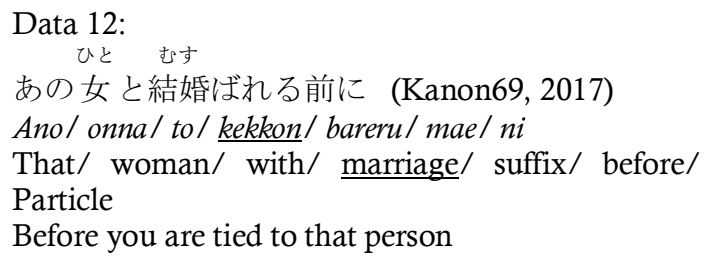

In Data 12, the word "kekkon" or marriage are read as "musubareru" or "to be tied to something". In this context, "ties" means relationship. Even though musubareru doesn't essentially means marriage, the kanji in the lyrics clarified what the singer meant. Since "relationship" is a more general word compared to "marriage", this use of ateji can be concluded as synecdoche.

Data 13:

とき
彼は今最期の瞬間 (BuzzG, 2010)
Kare/ wa/ ima/ saigo/ no/ shunkan
$\mathrm{He} /$ Particle/ now/ last/ Particle/ second
He is now in his last moment

The Data 13 above wrote the kanji "shunkan" to be read as "toki". In Japanese, toki is a general word for time. It can be translated as moment/occasion/season depending on the sentence. Meanwhile, shunkan means time in a shorter sense, like a blink of an eye or an instant moment. Thus, it can be concluded that the ateji in Data 13 are used similarly like Data 12, in which a word with broader meaning is used as the sound while it is written with a word with more specific meaning.

Data 14:

悔しいけどあなたの瞳には映らなくて (Nagaya, 2018)

Kuyashiil kedol anatal nol hitomil ni wal utsuranakute

Frustrating/ but/ you/ Particle/ pupil/ Particle/ not reflected

It is frustrating, but ( $\mathrm{I}$ am) not reflected in your eyes
Data 14 used the word "hitomi" to be sounded as " $m e$ ". Each word respectively means pupil of an eye and the organ, eye. Thus, it can be understood that hitomi is a small part of me. By using the bigger term of word (eye/me), the lyrics is saying a small part of the eye. And thus, this ateji is used similarly like how synecdoche is used.

\section{Ateji as Other Figure of Speech}

Though this research is centered on Japanese hiyu hyougen, there are still other ateji uses that are not included in the category. As such, this paper will also elaborate lightly on other figurative speech found in ateji usage.

Data 15:

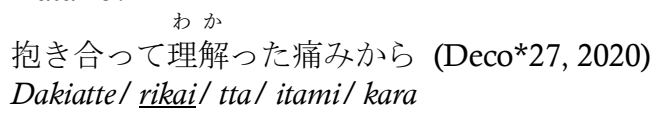

Hugging each other/ understand/ suffix/ pain/ because

Because I understand the pain of hugging each other

Data 15 utilizes the word wakaru/wakatta written as the kanji "rikai". These words are synonymous to each other as both means "to understand". The use of synonymous words in one sentence is usually seen as a mistake but it can also be seen as a style of speech known as tautology. In tautology, synonymous words are written in one sentence as a repetition to emphasize a statement (Nillas \& Nufus, 2014; Waridah, 2014). In Japanese, this usage is commonly known as kasanekotoba or juugen, a writing style that repeats words with similar meaning in one sentence to add more information or to give emphasize on the related words $(\mathrm{Yu}$, 2009).

Data 16:

$$
\text { げんそう }
$$

抱えきれないほどの現実を (40meterP, 2013)

Kakae/ kirenai/ hodo/ no/ genjitsu/ wo

Hold/ cannot completely/ Particle/ Particle/ reality/ Particle

The fantastical reality that cannot be grasped completely

The ateji in Data 16 is opposite of the previous data, as it uses antonymous words in ateji. The data above reads as gensou/fantasy, but is written as genjitsu/reality. Gensou semantically means "things that are not real", meanwhile genjitsu means "real things that can be seen in front of 
one's eyes". In this case, the meanings inside the ateji are paradoxical. Paradox, or gyakusetsu, is a figure of speech where one uses contradictory words to emphasize a point (Nillas \& Nufus, 2014; Prihantini, 2015; Waridah, 2014; Yuasa et al., 2011). By combining gensou and genjitsu as a singular word, the contradiction developed an emphasis inside the song, showing the singer's confusion and denial of the world that is happening around them.

Data 17:

あの人

母さんは? (Honeyworks, 2020)

$\underline{\text { Kaasan } / w a ~}$

Mother/ Particle

What about Mom?

Ateji can be used to clarify subjects of a sentence. In Data 17, the furigana ano hito/that person is clarified by kanji of kaasan/Mom. Semantically, ano hito is a third-person pronoun used to talk about someone that is not closely related to the speaker, like an acquaintance or a stranger. Yet, in this lyric line, the singer is talking about his own family, which is his mother.

In Data 17, ateji is used like litotes or kanjohou, which is an understatement of things to express something greater than what is mentioned (Nillas \& Nufus, 2014; Prihantini, 2015; Waridah, 2014; Yuasa, et al., 2011). By expressing the singer's mother as someone who is not close to him, listeners are able to know the relationship between the mother and the son.

\section{CONCLUSION}

Based on the analysis done in this research, it is known that there are four types of ateji found in Japanese song lyrics. The ateji types found based on the data analysis are ateji of foreign language, ateji of pronouns, ateji of word substitution, and ateji of specific works. Within those four types, ateji of word substitution has the most frequencies. It is also known that all ateji of word substitution and ateji of specific works are used as figurative speech, either as metaphor, metonymy, synecdoche, or other figurative speech. Since more than half of the data is categorized as ateji of word substitution, more than half of the ateji is also proven to be able to be understood as figurative speech.
The analysis also concluded that there are certain patterns on the selection of words used in ateji. The words can be correlated by similarities or shared value based on the context of a story, resulting a metaphorical effect on the ateji. They can also be tightly related through concepts, similar to metonymy. Words in ateji can also connected as general meaning and specified meaning, as found in synecdoche. Lastly, they can also have semantical relation like synonyms and antonyms, resulting in similar patterns found in other figurative speeches such as tautology and paradox.

\section{REFERENCES}

Ana, J., \& Divna, T. (2012). Contrastive study of the metaphor and metonymy driven semantic extensions of the body part word hand “手” in Chinese and Japanese language. Doğu Arașttrmalar, (10), 181 - 192. Retrieved from https://dergipark.org.tr/en/pub/doguedebiyati/iss ue/53738/719666

Lee, T. U. (2020). Doushi "nobasu" no tagikozo Nihongo kyoiku no kanten kara -. Nihongo-Nihon Bunka Ronshuu, (27), 1-29. https://doi.org/doi.org/10.18999/nagdnn.27.1

Lewis, M. (2010). Painting words and worlds. Columbia East Asia Review, 3(2), 28-45. Retrieved from http://www.eastasiareview.org/issues/2010/article s/Lewis_Mia.pdf

Nakazawa, S. (2020). Kokokoza. Retrieved from https://www.nhk.or.jp/kokokoza/tv/basickokugo /archive/chapter031.html

Nillas, R., \& Nufus, H. (2014). Pedoman Resmi EYD: Ejaan Bahasa Indonesia yg Disempurnakan (Aya, ed.). Jakarta: Wahyu Media.

Prihantini, A. (2015). Majas, Idiom, dan Peribahasa Indonesia Superlengkap (Pritameani, ed.). Yogyakarta: B First (PT Bentang Pustaka).

Shirose, A. (2012). Ateji no gendai youhou ni tsuite. Tokyo Gakugei Daigaku Kiyou, Jinbun Shakai Gakka$\mathrm{Kei}$, 63, 103-108. Retrieved from http://hdl.handle.net/2309/125467

Sugiyono. (2013). Metode Penelitian Kuantitatif, Kualitatif, dan R\&D. Bandung: Alfabeta.

Waridah, E. (2014). Kumpulan Majas, Pantun, dan Peribahasa plus Kesusastraan Indonesia (R. Renggana, ed.). Bandung: Ruang Kata.

Yu, X. M. (2009). Tautology and collocation: A study of their relationship and recognition. Hokuriku Daigaku Youki, (33), 125-141.

Yuasa, M., Itoku, S., Iwai, Y., Oketani, I., Nagamatsu, N., Minami, I., \& Yamami, H. (2011). Kokoku wo Kyaria ni Suru Hito no Chonyumon: Kokoku-Koho no 
Kiso kara Hassouho, Netto Kokoku Made. Tokyo: Sanwa Shoseki.

\section{DATA REFERENCES}

40meterP. (2011). I Hatsune Miku(40meter) I Torinokoshiti Torinoko City IOriginal I [Video]. Retrieved from https://youtu.be/yIQDGwyJpSo

40meterP. (2013). 【Hatsune Miku(40meter)】 Ame to Asphalt /Original PVJ [Video]. Retrieved from https://youtu.be/zsTrukFHHYc

BuzzG. (2017). 【Hatsune Miku】 GALLOWS BELL I Original! / [Hatsune miku] GALLOWS BELL [Official Video] [Video]. Retrieved from https://youtu.be/az8WM1jY-rQ

BuzzG. (2019, April 17). IGUMI】 Hoshi no Uta I Original! / / [GUMI] Star's song [Official Video] [Video]. Retrieved from https://youtu.be/YQXXInWRWgU

CHiCO with Honeyworks. (2015). CHiCO with HoneyWorks 『Ai no Scenario』 [Video]. Retrieved from https://youtu.be/P_At3pIE5BU

Deco*27. (2009). [Hatsune Miku] More Than You, Less Than Me。 [Original Song] [Video]. Accessed from https://www.nicovideo.jp/watch/sm8298201

Deco*27. (2019). DECO*27 - Relationship Scramble feat.
Hatsune Miku [Video]. Retrieved from https://youtu.be/nj82E1_70sQ

Deco*27. (2019). DECO*27 - We The Hostages feat. Hatsune Miku [Video]. Retrieved from https://youtu.be/d_svmw65Mgk

Deco*27. (2020). Pseudo-Hope Syndrome feat. Hatsune Miku [Video]. Retrieved from https://youtu.be/KgczJh0uX5o

Eve. (2017). Dramaturgy - Eve $M V$ [Video]. Retrieved from https://youtu.be/jJzw1h5CR-I

Honeyworks. (2020). I MV I Samishigariya feat. Shibazaki Ken×Shibazaki Aizou (CV : Eguchi Takuya - Shimazaki Nobunaga) / HoneyWorks [Video]. Retrieved from https://youtu.be/EK6_Snqko_U

Ito, K. (2016). IFukase】 Time Traveler IItou Kashitarou I [Video]. Retrieved from https://youtu.be/Je6dCVfHvkU

Kanon69. (2017). KANON69 "First Lady" MV [Video]. Retrieved from https://youtu.be/tUXvfybhkxI

Natsushiro, T. (2017). Nia / Natsushiro Takaaki MV [Video]. Accessed from https://youtu.be/7uacnNTk7I8

Noboru. (2014). Shiroi Yuki no Princess wa - Noboru个 feat. Hatsune Miku [Video]. Retrieved from https://youtu.be/aPb-MTcpNbE 